\title{
Effect of Investment Risk on Unit Trust Price Volatility Among Capital Market Authority Listed Firms in Kenya
}

\author{
Joseph Kimani Mwangi ${ }^{1}$ Prof. Willy Mwangi Muturi ${ }^{2}$ Dr. Patrick Kibati ${ }^{3}$ \\ 1.Phd Scholar. Department of Economic, Accounting and Finance, Jomo Kenyatta University of Agriculture \& \\ Technology, Nairobi, Kenya, PO box 1063- 20100, Nakuru, Kenya \\ 2.Phd Lecturer. Department of Economic, Accounting and Finance, Jomo Kenyatta University of Agriculture \& \\ Technology, Nairobi, Kenya, PO box 62000- 00200, Nairobi, Kenya \\ 3.PhD Lecturer. School of Business and Economics, Kabarak University, Nakuru, Kenya, PO Private 20157, \\ Nakuru, Kenya
}

\begin{abstract}
The purpose of the study was to investigate the effect of investment risk on unit trust price volatility among CMA listed firms in Kenya. As a result of unit trust price volatility, investors are shifting to real estate and other investments with low price volatility. This makes unit trust price volatility an important issue to investigate. The unit trust price volatility is of much importance to investors, fund's managers and government regulators. The objective that guided the study was to investigate the effect of investment risk on unit trust price volatility. A record survey sheet was used to collect secondary data using longitudinal research design. The statistical population of the study consisted of 19 Unit trusts registered by CMA 2016 and offering equity fund. Census was taken to collect annual data for a period of 9 years from 2009 to 2017. Data presentation was done using panel plots, trend lines and distribution tables. The statistical techniques used are descriptive statistics such as Mean, median and Standard deviation. Diagnostics tests done were multicollinearity, autocorrelation, normality, Heteroskedasticity, Hausman and serial correlation. Correlation tests, analysis of variance and panel regression analysis were also done for Inferential statistics. The hypothesis of the study was tested using panel regression analysis. The null hypothesis of the study was rejected at $5 \%$ level of significance. The results $(\mathrm{r}=-\mathrm{O} .4366)$ of the study indicated that the effect of Investment risk on unit trust price volatility was negative and statistically significant at 5\% levels. The overall model was tested using the F-test at 5\% level of significance which resulted to the value of $\mathrm{F}(0.05,1,84)=3.96 \leq \mathrm{F}(1,83)=19.550$, p-value $=0.000 \leq 0.05$ indicating that the model fits well. The results of the study analysis revealed that investment risk had a statistical significant effect on unit trust price volatility among CMA listed firms in Kenya for equity fund model. The coefficient of determination $\left(\mathrm{R}^{2}\right)=0.1906$ which indicated that the investment risk contributes only $19.00 \%$ of the unit trust price volatility while the larger proportion is attributed to other extraneous variables. The model can be used for unit trust price volatility prediction though on a low scale. The study made the following recommendations; CMA regulate and inspect the financial stability policies governing unit trusts, unit trust firms to pay the investors in time and improve on financial stability, reduce on the operation costs and control operation systems of unit trusts. On policy implication, the government should review the CMA act to give the authority the inspection mandate on the unit trust to make them efficient and conform to financial international standards to be in line with the economic pillar of vision 2030.
\end{abstract}

Keywords: Investment risk, unit trust price volatility

DOI: $10.7176 / \mathrm{RJFA} / 10-8-05$

Publication date: April $30^{\text {th }} 2019$

\subsection{Introduction}

The birth of unit trust industry dates back to a European Dutch merchant Adriaan Van Ketwich in 1774. After the financial crisis from 1772 to 1773 he created the first closed-end fund of 2,000 shares (Gilchrist, 1976). These provided diversification for small investors. Acute increase in price volatility has been witnessed in most western countries in the past but in nineteen nineties low price volatility was evidenced in the same countries in the Security Market (Liang \& Wei, 2012). Li and Zou (2014) revealed that price volatility resumed a decreasing trend in 2001 after a large increase between the years 1997 to 1999 . The mean estimate of annual historical price volatility over the 15 years was below levels of 15 to 20 percentage point experienced between 1997 and 1999 (Tari \& Yıldırım, 2009). The sequence of price volatility in developed markets is similar showing a gradual increase in their correlation for the last 15 years (Tari \& Yıldırım, 2009). However, the sequence of price volatility in Japan Market was different.

The unit trusts return trails below the returns of bonds and equities traded in NSE though a positive growth is projected by CMA to be higher in future (CMA, 2015). Little documentation is available on the relationship between investment risk and unit trust price volatility. The risk - return preference of unit trust investment behaviour is significant and also need to be considered in any natural investment decision (Bodies, Kane \& Marcus, 2008). The decline in unit trust firm's equity position fair value depends on Equity investment risk bearing in mind that the financial institutions instruments are based on equity investment. The loss in returns on investment and 
capital invested arise as a result of decline in the value of equity position which depends on the direct and inverse investment (Chow \& Hsu, 2013). The unit trust investing behaviour based on their risk return should be considered significantly to reduce the asset - liability mismatch arising as a result of greater investment risk with an aim of higher expected returns thereby affecting the benefits of the unit trusts in the long run (Soh, Cheng \& Nasir, 2009). The reduction in unit trust actual and future payoff has arisen from the erosion of its financial position as a result of the financial markets crisis adversely affecting investment risk (Bchini, 2013). Some investors take more investment risk in unit trust than other is an issue that was investigated by this study for a period of nine years $(2009$ - 2017).

In Kenya, the idea of unit trust did not begin until the enactment of The Capital Markets Authority (CMA) that is empowered under Section 30 of the Capital Markets Act to approve institutions to promote Collective Investment schemes under Capital Markets (Collective Investment Schemes) Regulation, 2001). A copy of prospectus is deposited and approved by CMA identifies the unit trust functions and funds. Unit trust provide individual investors who do not want to actively buy or sell securities on their own, the opportunity to still pursue their desire of investing in financial securities by acting as a form of financial intermediary (Gachiri, 2013). Investment decision making is a significant process for investors in order to maximize profit and hence optimize wealth in the long run (Brown, Keith \& Reilly (2000). The process of decision making requires an investor to consider all available information on the investment. In securities market, all decisions related to investment are influenced by information sources. The information is collected from some sources such as news media, financial analysts, financial statements of companies and even securities market prices (Budiono, 2009).

Unit trust has been termed as safe haven for less complicated and less capitalized conservative investors in the market that is proving complicated. Investors can invest any sum of money in a unit trust, thus it's an easier way of investment diversification. It is important to understand the risk associated with the instruments that the management companies invest in, as it depicts the overall risk of the fund. The collective investment scheme offers regular income plan, growth plan, equity funds, debt funds and balanced fund schemes. There was a sharp decline in the unit trust industry at the beginning of 2007, accounting for over $32 \%$-unit trust price drop. As a result of this decline, the industry suffered and was only able to experience an upswing in price at the start of 2009 (CMA, 2010).

The unit trusts return trails below the bonds and equities traded in NSE though its growth is projected by CMA to be higher in future. Lack of popularity and poor performance of unit trusts has been evidenced in Kenya despite the increased intellectual assets investments. The effect of macroeconomic variables in solving the issues facing unit trust price variation is questionable which is among the financial concern for investor in the long run. According to the Capital Markets Authority (CMA, 2015) report, unit trusts have grown in acceptance and popularity in Kenya from virtually zero in 2001 to twenty-three as per those licensed by May 2015 .

As a result of this decline, the industry suffered and was only able to experience an upswing in price at the start of 2011 (CMA, 2012). The industry over the years has proved very popular among investors who see it as a safe haven and this has resulted in the ever increasing number of unit trusts in the country. To buttress this fact, the number of listed funds in the country now has increased significantly in the last 8 years. As at 2012, there were 16 listed unit trusts, but today the figure stands at 24 unit trusts in Kenya.

\subsection{Statement of Problem}

Poor Market condition with unpredictability and uncertainty investment has brought a ripple effect on the performance of unit trust firms leading to a decline on net retail sales by 55\% in comparison to the year 2012 in South Africa (Petrasek, 2014). There was a sharp decline in the unit trust industry at the beginning of 2007 , accounting for over $32 \%$-unit trust price drop. As a result of this decline, the industry suffered and was only able to experience an upswing in price at the start of 2011 (CMA, 2012). The unit trusts return trails below the returns of bonds and equities traded in NSE though a positive growth is projected by CMA to be higher in future (CMA, 2010).

The trend of the unit trust price is uncertain and unpredictable with annual volatility ranging between $0.52 \%$ to $38 \%$ for the last seven years (Economic Survey, 2014). Due to the unit trust price volatility, investors are shifting to real estate and other investments with low price volatility (Economic Survey, 2014). By the nature of its operations, unit trust industry faces a myriad of challenges which lead to unit trust price volatility (Petrasek. 2014). However, the variables responsible for the unit trust price volatility have not been adequately documented in Kenya. Also the collapse of some banking institutions such as Chase bank, Dubai and Imperial bank has a significant impact on the operation of the unit trusts. Genghis, Dry associates, chase assurance and Apollo which had $80 \%$ of its deposits in these banks that are under receivership (CBK, 2016).

Most of the studies carried out are on political, environmental, interest rate, credit and liquidity risks on firms' performance. In every business decision and entrepreneurial act is connected with financial risk (Stroeder, 2008). Little attention has been paid by scholars in examining the effect of investment risk on the price volatility of unit trusts. In view of this gap in knowledge, the study aims to examine the effect of investment risk on unit trust price 
volatility among CMA listed unit trusts in Kenya.

\subsection{Objective of the Study}

The purpose of this study is to investigate the effect of investment risk on unit trust price volatility among CMA listed unit trusts in Kenya.

\subsection{Research Hypothesis}

Ho1. Investment risk has no statistical significant effect on unit trust price volatility among CMA listed unit trusts in Kenya

The study was of particular interest to the CMA and NSE who are the regulators. The study offered informed advice to the relevant authority and investors on financial risk and unit trust price volatility. The study acts as the foundation for further research on the practicability of the model in investment risk and unit trust price volatility locally. The research is useful for scholars and researchers who would wish to further discuss or carry out further research on unit trust price volatility.

\subsection{Scope of the Study}

The research focused on unit trusts registered by CMA in Kenya (CMA, 2016). The target population was 19 unit trusts registered with CMA and offering Equity fund for secondary data.

\section{LITERATURE REVIEW.}

\subsection{Theoretical Review (Efficient Market Hypothesis (EMH) Theory)}

The efficient market theory was developed by Eugene Fama in 1970. Fama (1970) argued that the efficient market theory is an investment theory where by security prices reflect all the relevant information in the market and that generating a consistent alpha is not possible. He also revealed that neither technical nor fundamental technique can produce risk- adjusted return or alpha consistently but inside information can result in the risk - adjusted returns.

Malkiel (2003) described Efficient Market Hypothesis as a hypothesis which claims that financial markets are "informational efficient". Malkiel (2003) sited three basic forms of EMH, namely; strong, semi-strong and weak. The strong form of EMH states that it is unlikely for investors to beat the market as market prices reflects all relevant information both public and non-public. The semi-strong form of EMH states that it is unlikely that investors will beat the market by using only publicly available information on prices. The weak form of EMH states that it is unlikely for investors to beat the market using historical information on prices and volume. The concept of EMH is associated with the idea of "Random Walk" model which states that price movements from one period to another are independent and as such they are said to follow a random walk.

The idea behind the random walk model is that if the information flow is unhindered and unit trust prices quickly reflects all information, tomorrow's price change will reflect only tomorrow's news and will be independent of the change in price today. This theory has been backed by a large number of empirical evidence and this shows that it may be a herculean task to identify mispriced unit trust (Shikuku, 2012).

If this theory holds, it means that it will be a futile venture by fund managers to devote large amount of resources to the search of mispriced unit trust (Sharpe, 1966). According to Hao \& Zhang (2007) the concept of EMH suggests that active investors will obtain alphas that are equal to the negative of the cost they incur as a percentage of the assets. Furthermore, Mabhunu (2004) argues that it is likely that investors are able to produce higher returns by employing the indexing strategy than they are likely to produce through active management of funds. Despite the continued support of EMH by researchers, especially in the 1970s and 1980s, cracks began to appear in the model in the early 1990s (Malkiel, 1996). The increasing use of dividend yields, price- earnings ratios and market capitalization to predict security returns suggested that returns on security may not actually be independent over time.

Creswell, (2003) analyzed the mutual funds' performance and argued that the result obtained disagreed with the notion that research fees and trading expenses are wasted. Due to the lack of alternative theories in the 1990s to reject the claims of EMH, researchers are unable to wholesomely reject the theory. Isik \& Acar (2004) suggested that the strategy of managing a fund passively can only be justified if the market is inefficient. When information about an individual stock surface, such information is usually reflected in market prices almost immediately, thus passive management may become attractive as the markets appear to be efficient in digesting information and adjusting to them.

The advocates of EMH and the random walk theory suggest three important facts. One is that future performance cannot be predicted by mere use of past performance. The second conclusion is that top managers may not be able to beat the market in the future and lastly, active fund managers may not be able to make higher returns over the passive strategy.

The summary is that fund managers or professional investors do not necessarily need to have superior skills to identify securities or time the market (Cheng \& Nassir, 2010). Kamil, Subramaniam, Ali, Musah and Alex (2018) 
noted that the unit trust funds ownership allocation is determined by the capital market. The market price provides signals for allocation of resources in which firms make investment decision where investors choose the securities that represent ownership of firms' activities under the assumption that the securities prices at any time fully reflect all available information. Fama (1970) attempted to formalize the theory and organize the growing empirical evidence. He presented efficient market theory in terms of a fair game model, contending that investors can be confident that a current market price fund reflects all available information about a unit trust which make Efficient Market theory relevant to investment risk on unit trust price volatility.

\subsection{Conceptual Framework}

To interpret knowledge for empirical application in a comprehensive manner, a conceptual framework was provided by theory in order to hold existing and new knowledge. For the purpose of the study, conceptual framework comprised of independent variable and one dependent variable.

Independent Variables

Dependent Variable

Investment risk

annual income to expenses ratio

UNIT TRUST PRICE

VOLATILITY

Net Asset Value (NAV)

Independent and dependent variables related to the study are conceptualized in Figure 2.1. Statistics of independent variables was used to measure the effect of investment risk in the study. Investment risk was measured using annual income to expenses ratio. The dependent variable is the unit trust price volatility which was measured using the standard deviation of NAV.

\subsection{Investment Risk and Price Volatility}

Chow and Hsu (2013) revealed that investment risk is a function of business risk and can generally be interpreted as the short comings of a specific business or initiative. This is entirely the disturbance in a business financial position setup. The occurrence of numerous great profiling of financial failures in the recent past that include security market crash of 1987 (Carlson, 2006), the Asian Contagion that is also referred to as financial crisis of 1997 - 1998 (Lowenstein, 2000) and "the Big short" of 2007 - 2008 financial crisis (Lewis, 2010) implies that investment risk has proven a difficult issue in financial management.

The theory of risk- returns emphasis on the investor's maximization of returns and minimization of risk in the long run. The comfortability and satisfaction of an investment depends on returns accrued and the risk an investor can bear (Brooks, 2013). Hence risk returns trade off states that an investor must be willing to accommodate greater risk to acquire greater returns (Pandey, 2008). Return $=$ Risk - free rate $+\beta$ (Risk premium) is the association between risk and returns which are direct proportional. This proves Pandey (2008) argument on risk and returns that the higher the risk, the higher the returns in the long run but proper balance should be maintained to maximize the value of firm's shares. In the start- up stage, higher risk investors often perform below lower risk investors in the short run but contrary investors' expectation is for higher risk investments to earn higher returns in the long run (Cornett, 2009).

The decline in unit trust firm's equity position fair value depends on Equity investment risk bearing in mind that the financial institutions instruments are based on equity investment (Brown, Keith \& Reilly, 2000). The loss in returns on investment and capital invested arise as a result of decline in the value of equity position which depends on the direct and inverse investment (Jamaldeen, 2014).

The unit trust investing behaviour based on their risk return should be considered significantly to reduce the asset - liability mismatch arising as a result of greater investment risk with an aim of higher expected returns thereby affecting the benefits of the unit trusts in the long run. The reduction in unit trust actual and future payoff has arisen from the erosion of its financial position as a result of the financial markets crisis adversely affecting investment risk (Bchini, 2013). Some investors take more investment risk in unit trust than other is an issue that needs to be investigated by this study for a period of ten years $(2009-2017)$.

The percentage of equities in the investment portfolio is the measure usually used for investment risk which is referred to as equity allocation (Bchini, 2013). Volatility of balance sheet and income for liability - driven investors is exposed by Equity investment. Mean reverting for equity prices can be achieved through rebalancing to avoid losing the entire capital which is the essence of risk but annual mean reversion of at most $5 \%$ and high volatility is the empirical evidence (Balvers, 2000) and (Spierdijk, 2010). The reduction of returns under mean reversion can be as a result of upward markets behaviour in feedback trading which is also risky but provides experience to investors in risk taking over time (Bouch, Clark \& Groslambert, 2004).

\subsection{Critique of the Existing Literature Relevant to the Study}

Maina (2013) sought to establish the relationship between the risk and return of investment channels available to 
insurance companies in Kenya and found that risk and return had a no significant effect on investments held by insurance companies. The study was carried out on ten insurance companies based on the investments data for the period 1st January 1997 to 31st December 2001.The objectives of the study were to establish if there are differences in return across companies for investment in similar assets and whether there existed a correlation between the risk and return on investments undertaken by insurance companies in Kenya. The study established that there was no relationship between mean rate of return and risk on investment. From the findings, there appears to be very little correlation between the return and risk of investments held by insurance companies. Maina (2013) revealed that return and risk have a relationship does not hold for investments held by insurance companies in Kenya.

Correa, lee, Sapriza and Suarez (2014) also found that political, social, financial and economic stability affected the investment risk. Foran and O'sullivan (2013) found a negative significant effect of economic, political, financial and country risks on security prices. Spiegal (2006) studied the Russian security market and revealed a significant sensitivity of security prices to macroeconomic variables but economic risk had a price declining effect on security prices. Girard and Omran (2007) conducted a research on Arab capital markets and found that large security market outside America had a greater risk than small security markets in respective country risk but a negative effect on security returns was noted for economic and political risks. In another study, Girard and Omran (2007) found that political risk had significantly greater effect on security prices than economic risk.

\subsection{Summary}

Studies have been carried out mainly in US, Great Britain, Australia and Japan. Very few studies outside these countries have been done due to the fact that unit trusts are relatively new investment in many parts of the world. Saunders, Lewis and Thornhill (2007) present comparative data for 60 large pool schemes in Kenya, Europe and USA. The data revealed that in Kenya, $50.2 \%$ of the fund is invested in real estate compared to $34.2 \%$ and $53.1 \%$ in Europe and USA respectively. Bonds and bills took up 16.3\% of the Kenyan fund while they took up $12.6 \%$ and $22.7 \%$ of the European and American funds respectively. Offshore investments only formed $5.5 \%$ of the Kenyan fund compared to $26.5 \%$ and $11.1 \%$ of the European and USA funds respectively. The fund managers have a good reason for making such investment decision. The different proportions in the different countries could be due to the different factors in these countries.

Omonyo (2003) observed that risk and return are the key considerations in investment practices of unit trust in Kenya. He dealt on effect of general risk on returns. Foran and O'sullivan (2013) found a negative significant effect of economic, political, financial and country risks on security prices. Spiegal (2006) studied the Russian security market and revealed a significant sensitivity of security prices to macroeconomic variables but economic risk had a price declining effect on security prices. Both Spiegal (2006) and Foran and O'sullivan (2013) concentrated on political, economic, country and financial risk and other macroeconomic variables. The effect of investment risk on price volatility has not been discussed.

In Kenya, unit trusts have been in operation since 2001. Sharpe (1966) carried out a study on returns from 34 unit trusts from 1954 to 1963 to estimate the correlation between reward Volatility (R/V) ratio and NAV. The R/V ratio was calculated as funds mean annual return less pure interest rate divided by the standard deviation annual rate of return. The findings revealed that $\mathrm{R} / \mathrm{V}$ ratio was positively related to the NAV and the $\mathrm{R} / \mathrm{V}$ ratio of larger funds was small. The discussion on the impact of funds' Size on the performance concluded that the larger funds attained a given level of security analysis by utilizing little of its returns than smaller funds. Jones (2012) findings indicated that investors should regularly monitor the size of the funds bearing in mind that the funds size is dynamic over the years.

There have been many investigations on the determinants of unit trust performance and the effect of financial risk on returns. Most of the risks covered in most of the studies are political, economic, country and general financial risks. Several studies have been carried on Credit risk and market risk management but establishment in estimates of investment risks components and price volatility has not been adequately covered.

There have been very few studies on the effect of investment risks factors on the unit trust price volatility. In addition, there have been many controversies and limitations in the prior investigations on investment risk and returns. Therefore, all these shortcomings made it necessary to conduct a more extensive research on this issue. From the above review of literature, it's evident that few studies have been carried out in investment risk and volatility of unit trust price in Kenya.

\subsection{Research Gap}

Limited empirical studies on effect of investment risk on unit trust price volatility have been carried out. Much of the research done on the Price volatility of unit trusts and investment risk has been carried out in the developed economies where pooled funds are at very advanced stages. The unit trust price volatility depends mainly on the expertise of the fund managers and the price of the underlying assets or securities. In addition, most of the research work carried out has been on whether the funds outperform the market, persistence of the fund returns and effect on certain attributes on the fund performances. Regarding the financial liquidity and returns, 
Most of researches done dealt on political risk, country risk, interest risk, force majule risk, economic risk and liquidity risk. The choice of the components of investment risk was on the basis of relationship to unit trust price volatility. Credit risk was eliminated since its related to lending contrary to default risk. In addition, there have been many controversies and limitations in the prior investigations about these issues. Therefore, all these shortcomings made it necessary to conduct a more extensive research on the effect of investment risk on unit trust price volatility among CMA listed firms in Kenya.

\section{RESEARCH METHODOLOGY}

The research philosophy is classified into three major components namely ontology, epistemology and axiology which are significant in research. The philosophical approaches are the best enablers in decision making on the research methodology to adopt based on the objectives (Saunders, Lewis and Thornhill, 2009). The data collection and hypothesis formulation was adopted, tested and confirmed to be used for further research.

\subsection{Research Design}

The study adopted longitudinal research design to collect panel data since the design attempts to explore effect to make predictions on the longitudinal data for the period 2009 to 2017 . The research design was used to identify, describe, show relationships and analyze variables of investment risk that affect unit trust price volatility in Kenya. The target population for the study was 19 unit trusts as per the CMA listing in May 2016 that offer equity and money market fund. The study adopted a record survey sheet to obtain secondary data as recorded in financial statements and factsheets of the firms from CMA, NSE, websites and Kestrel surveys. The research strategy is based on data collection and hypothesis development.

\subsection{Sampling Frame}

For the purpose of this study sampling frame constituted of unit trust firm that were contained in the CMA 's 2016 directory. Cooper and Schindler (2011) define a sample frame as a list of subjects where a sample is actually drawn. It is a list containing items from which the sample is drawn (Kothari, 2004).

\subsection{Data Collection Procedure}

The researcher got permission from the Board of post graduate school of Jomo Kenyatta University of Agriculture and Technology, then obtained a research permission from the National Commission for Science, Technology and Innovation (NACOSTI) and other relevant government agencies in Kenya. A list of unit trusts was obtained from Capital market authority official website of which 19 unit trusts were identified to participate in data collection. The secondary data was collected through the use of record survey sheet from financial statements and factsheets that was obtained from CMA, unit Trusts offices, kestrel survey on unit trust returns, performance and fund management, and the websites. The results of the data were to be treated with maximum confidentiality.

A pilot study was carried out to check on validity and reliability of instruments in gathering the required data and the reliability statistics results are as indicated in the table 3.1. Two independent resource persons having interpretation skills on financial risk and price volatility examined the instrument to ensure content validity. Also the research supervisors examined the content validity. The resource persons evaluated the variable for relevance, meaningfulness and clarity. The instrument was adjusted accordingly for the final data collection.

\section{Table 3.1 Reliability Statistics}

\begin{tabular}{llll}
\hline Variable & Number of items & Cronbach Alpha Coefficient & Recommendation \\
\hline Investment Risk & 1 & 0.878 & Acceptable \\
Price Volatility & 2 & 0.742 & Acceptable \\
\hline
\end{tabular}

The Cronbach alpha coefficients were used to determine reliability of the record survey sheet. Cronbach's Alpha ranges in value from 0 to 1 . The reliability analysis for this pilot study yielded an alpha of 0.878 and 0.742 which implied that the data collection tool was reliable. A coefficient equal to or greater than 0.7 is considered to be acceptable (Gliem \& Gliem, 2003).

\subsection{Data Analysis}

The data was organized and financial ratio computed using Excel software in order to obtain the research variables. As a result of unbalance data for cross-sectional units, the average per year of independent and dependent variables was computed depending on the number of sub variables. The mean, median maximum, minimum and standard deviation of the financial ratios were computed and the study also applied quantitative analysis.

The research variables were analyzed quantitatively by panel regression model using STATA version 13.0 and Gretel analysis tool. The stationary structure of the longitudinal data was tested using the Durbin-WuHausman and Hausman test for the results obtained from the regression analysis to reflect the actual relationship since non stationary structure series yields to spurious regression problems (Granger \& Newbold, 1974 and 
Gujarati, 2004).

\subsection{Correlation and Regression Analysis}

The violation of assumptions of OLS method that the variables are not strongly collinear impairs the estimation of its parameters. The diagnostic test for the parametric data conducted are multicollinearity, autocorrelation, serial correlation, Hausman, Durbin- Wu-Hausman, heterosckedasticity, normality for residue and Breusch-Pagan test statistic:

Regression analysis and ANOVA were used to test the effect of investment risk variable on the unit trust price volatility. The dependent variable was unit trust price volatility (Y), $\beta_{0}=$ Constant, independent variable was investment risk (IR) and $\varepsilon=$ Error term. In this study the panel data regression model was determined as; $\mathrm{Y}=\boldsymbol{\beta}_{o}{ }^{+}$ $\beta_{1} \mathrm{IR}+\varepsilon$

Descriptive analysis used frequency distributions and means, median and standard deviation as measured by percentages. Testing of the study hypothesis was done through the use of probability. The method of hypothesis testing or significance testing is said to be probabilistic only when the sample from the population is determined using probability sampling method (Mosteller, Rourke \& Thomas, 2000; King'oriah, 2004, Hsiao, 2013).

To test the significance effect of independent variable investment risk, have no significant effect on dependent variable that is $\beta_{1}=0$ and the alternative prediction that at least one of the independent variable was not equal to zero that is $\beta \mathrm{j} \neq 0 ; \mathrm{j}=1$. The hypothesis to test is here below stated;

$\mathrm{H}_{0}: \beta_{1}=0$

$\mathrm{H}_{1}$ : At least one of $\left(\beta_{1} \neq 0\right)$

The regression model was given by the following equation: $\mathrm{Y}=\beta_{0}+\beta_{1} \mathrm{X}_{1}+\varepsilon$.

\section{RESEARCH FINDINGS}

\subsection{Response Rate}

The financial statements for 14-unit trust firms representing $73.6 \%$ of the respondents were collected either from the firm's websites, main offices or CMA office. The official collected number of observations was 85 representing $67.5 \%$ of the observations. Most of the unit trust firms do not submit their financial statements to the CMA neither do they place them in their websites but store them in their offices in soft or hard copies. Kalunda (2012) reported a response rate of $70 \%$ in their study on pharmaceutical manufacturing companies in Kenya and their credit risk management practices. Mugenda and Mugenda (2004) assert that a response rate of more than 50\% is adequate for analysis. Jones (2012) also asserts that a return rate of 50\% is acceptable for analysis and publishing. Jones (2012) also stated that a $60 \%$ return rate is good and a $70 \%$ return rate is very good.

\subsection{Diagnostic Tests}

The parameters were diagnostically tested for multicollinearity, autocorrelation, normality, serial correlation, stationarity, Asymptotic and heterosckedasticity, Breusch-Pagan test statistic, Durbin- Wu-Hausman test and Hausman test.

\subsubsection{Multicollinearity Test}

Multicollinearity inflates the standard errors and gives spurious results therefore, it is important to test the presence of multicollinearity before running Ordinary Least Square (OLS) tests for instance the panel regression model. The results are as displayed in Table 4.1.

Table 4.1: Variance Inflation Factor Test of Multicollinearity

\begin{tabular}{lcc}
\hline Variable & I/VIF & VIF \\
\hline Investment Risk & 0.237 & 4.218 \\
Price Volatility & 0.307 & 3.260
\end{tabular}

Since the resultant VIF values were found to be less than 10, and tolerance levels (1/VIF) values found to be greater than 0.1 then the use of OLS to estimate the effect of investment risk on unit trust price volatility is applicable. Gujarati (2004) indicates that the signs of multicollinearity as estimation of coefficient differ from model to model. If the $\mathrm{t}$ statistics for specific gradient are not significant at $\mathrm{p}>0.05$ but $\mathrm{F}$ - test for all the gradients simultaneously zero significant at $\mathrm{P}<0.05$ then there a large correlation among parts of predators' variables.

\subsubsection{Autocorrelation Test}

The research investigated on the presence of autocorrelation using Durbin- Watson statistics. The statistic should be between $1.5-2.5$ (Cameron, 2005, Garson, 2012). The hypothesis to test was whether there was evidence of lack of autocorrelation as stated at $\alpha=0.05$, the rule of thumb was to reject Ho, if p- value was less than $\alpha$ else fail to reject Ho (Garson, 2012) where:

$\mathrm{H}_{0}$ : There was no evidence of autocorrelation

$\mathrm{H}_{1}$ : There was evidence of autocorrelation

The error term in multiple regression models is one of the assumptions of classical linear regression model. 
The researcher therefore sought to apply the Durbin-Watson test to establish the presence of autocorrelation. The results are as displayed in Table 4.2.

Table 4.2: Durbin-Watson Test of Autocorrelation

\begin{tabular}{lll}
\hline Test & Statistic & p-value \\
\hline Durbin-Watson & 1.848 & 0.0022 \\
\hline
\end{tabular}

Since the resultant Durbin-Watson statistic was $1.848<2$, p- value $=0.0022<0.05$, it is clear that there is no problem of autocorrelation. This justified the use of multiple regression model. The Durbin - Watson statistics is supposed to be between 1.5 and 2.5 (Cameron, 2005; Garson, 2012).

\subsubsection{Normality Test}

To check whether the data provided was normally distributed or not and for the purpose of subsequent analysis, the variables were subjected to normality test. If the variables are not normally distributed, then there would be an issue in subsequent statistical analysis until the variable assumes normality (child, 1990). Inferential statistical methods were used to infer about the underlying relationship within respective variables. The researcher used the Shapiro-Wilk test to test the normality of the study variables. The results are as displayed in Table 4.3.

Table 4.3: Shapiro-Wilk Test for Study Variables

\begin{tabular}{lcc}
\hline Variables & Statistic & $\boldsymbol{p}$-Value \\
\hline Investment Risk & 0.795 & 0.671 \\
Price Volatility & 0.849 & 0.694 \\
\hline
\end{tabular}

To test the normality of the dependent and independent variables, Shapiro - Wilk test was used. The test hypothesis formulated to test if the data was normally distributed was given by Ho and $\mathrm{H}_{1}$, set $\alpha=0.05$. The rule of thumb is to reject Ho, if p- value is less than $\alpha$ (Park, 2008; Garson, 2012).

Ho: Data is normally distributed at $5 \%$ level of significance

$\mathrm{H}_{1}$ : Data not normally distributed at $5 \%$ level of significance

If $\mathrm{p}$ - value $\geq \alpha$, accept Ho that the data is normally distributed and hence the data is suitable for further analysis. Since all the $\mathrm{p}$-values $>0.05$ for all the variables, the data for the variables came from a normally distributed population. This implies that the data as presented is suitable for further analysis.

\subsubsection{Durbin- Wu-Hausman test}

The Null hypothesis for the GLS estimates are consistent asymptotic test statistic with Chi-square $(1)=0.3721$ with $p$-value $=0.5420$. The null hypothesis cannot be rejected and hence random effect model is favorable for the regression on the combined fund model. The Null hypothesis for the Variance of unit - specific error $=0$ with asymptotic test statistic chi- square $(1)=0.3421$ with $\mathrm{p}$ - value $=0.5586$. The Hausman test statistic: $\mathrm{H}=0.37176$ with $\mathrm{p}$-value $=$ prob $($ chi-square $(1)>0.37176)=0.542047$ implies that a low $p$-value counts against the null hypothesis that the random effects model is consistent, in favor of the fixed effects model. The Durbin- WuHausman test for the null hypothesis that the independent variable and the error are uncorrelated (Verbeek, 2004). The parameter estimators are compared for consistency under both the null and alternative hypothesis and the one that consistent under the null hypothesis only. In case the difference is significant, the null hypothesis is unlikely to hold.

\subsection{The Serial Correlation Test}

The researcher used the Wooldridge Drukker test to test for presence of serial correlation. The results are as indicated in Table 4.4

Table 4.4: Results for Serial Correlation Tests

\begin{tabular}{lccc}
\hline Model & Independent Variable & F-value & P-value \\
\hline 1 & Investment Risk & 3.272 & 0.045 \\
\hline
\end{tabular}

According to results in Table 4.4 , the $\mathrm{p}$-value $=0.045<0.05$ indicating that there is no serial correlation. This shows that for the linear panel-data models, there are no biases of the standard errors which could have caused the results to be less efficient. Granger and Newbold (1973) indicated that errors in one-time period are positively correlated with errors in the proceeding time period which is referred to as positive serial correlation. Wooldridge Drukker test statistic is the best test for serial correlation with a range between zero and four. If the $p$ - value $<0.05$, then the conclusion was that there is no serial correlation and vise -versa.

\subsubsection{Heteroskedasticity Test}

Homoscedasticity reveals that the dependent variable has an equal level of variability for each of the values of the independent variables (Garson, 2012). The presence of heteroscedasticity is reflected when $p$ - value $<\alpha$. Lack of equal level of variability for each value of the independent variables is heteroscedasticity There is an assumption that residuals have a constant variance or are homoskedastic across time and individuals. The presence of Heteroskedasticity leads to the biasness of the standard errors of the heteroscedasticity. The results are as indicated in Table 4.5 . 
Table 4.5: The Result for Heteroskedasticity Tests

\begin{tabular}{lccc}
\hline & & \multicolumn{2}{c}{ Test for Heteroskedasticity. } \\
\hline Model & Dependent Variable & Chi-Square & P-value \\
\hline 1 & Investment Risk & $2.472 \mathrm{e}^{+0.6}$ & 0.000 \\
\hline
\end{tabular}

The results in Table 4.5 reveal that the $\mathrm{p}$-value $=0.000<0.05$ showing that there exists heterosckedasticity. Therefore, there is no biasness of the standard errors of the estimates.

\subsection{Research Findings}

\subsubsection{Descriptive Statistics for Investment Risk}

The study sought to summarize results of investment risk for equity fund among CMA listed unit trusts in Kenya using the descriptive statistics namely mean, median, and standard deviation. The results are as presented in Table 4.6.

\section{Table 4.6: Investment Risk Statistics}

\section{Parameters}

\section{Investment Risk}

\begin{tabular}{lc}
\hline Mean & 5.98 \\
Median & 6.25 \\
Std. Deviation & 3.98 \\
Minimum & 0.81 \\
Maximum & 11.74 \\
\hline
\end{tabular}

The findings indicate that the mean of the investment risk is 5.98 with the median of 6.25 and a standard deviation of 3.98. It was also established that the minimum investment risk of 0.81 was recorded in the year 2017 while the maximum of 11.74 was experienced in the year 2010 .

\subsubsection{Investment Risk Panel Plot and Trend}

The study further sought to establish the panel plot and trend for a period of nine years ranging from 2009 to 2017 . The results are as presented in Figure 4.1.

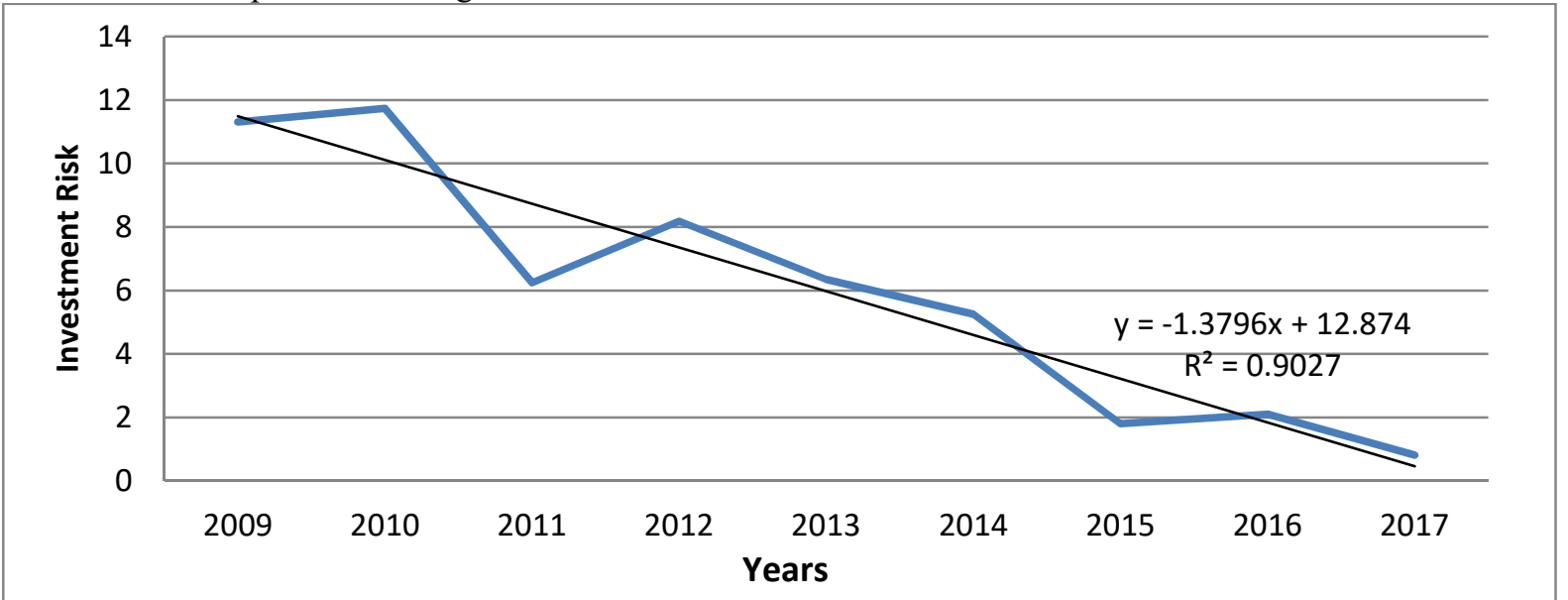

Figure 4.1: The Investment Risk Panel Plot and Trend

The study fixed a panel plot and trend for the investment risk for $2009-2017$ period. The curve shows the peak at the year 2010 and the lowest point at the year 2017. According to trend line that was fitted to the curve, there is a steep slope in the investment risk with change in time. This is shown by the negative gradient of -1.3796 with a y-axis intercept of 12.874. Andrew, Sam and Frank (2016) also reported a negative gradient in the study of current and future trends in investment management and investment performance. According to the resultant $\mathrm{R}^{2}=$ 0.9027 of the trend line, time as the independent variable explains a very large proportion of $90.27 \%$ of the change observed in the investment risk with a very little proportion explained $9.73 \%$ by the error term.

\subsubsection{Regression Analysis of Effect of Investment Risk on Unit Trust Price Volatility.}

The study sought to establish the effect of investment risk on price volatility for the equity fund by conducting regression analysis at 5\% level of significance. The results are presented in Table 4.7.

Table 4.7: Regression of Investment Risk on Unit Trust Price Volatility

\begin{tabular}{lccccc}
\hline & $\mathrm{B}$ & Standard Error & Beta & $\mathrm{t}$ & $\mathrm{p}$-value \\
\hline (Constant) & 2.384 & 0.834 & & 2.859 & 0.010 \\
Investment Risk & -0.362 & 0.143 & -0.472 & -2.531 & 0.021 \\
\hline
\end{tabular}

The effect of investment risk on unit trust price volatility for the equity fund yielded a coefficient of regression $\boldsymbol{\beta}=-0.362 \mathrm{p}$-value $=0.021<0.05$ and a constant term 2,384 , p-value $=0.010<0.05$. The constant term and beta 
value contribute significantly to the model though beta value contributes negatively. The regression model can be represented as $\mathrm{Y}=2.384-0.362 \mathrm{X}_{1}$, where $\mathrm{Y}=$ Unit trust price volatility and $\mathrm{X}_{5}=$ investment risk. The implication is that a change in one unit of investment risk decreases unit trust price volatility by 0.362 units. This implies that investment risk has a negative effect on unit trust price volatility that is statistically significant at $5 \%$ level of significance.

\subsubsection{Unit Trust Price Volatility among CMA Listed Unit Trusts in Kenya}

The study sought to summarize results of unit trust price volatility among CMA listed unit trusts in Kenya for Equity Fund. The study sought to summarize results of NAV for equity fund among CMA listed unit trusts in Kenya using the descriptive statistics namely mean, median and standard deviation presented in Table 4.8.

Table 4.8: Descriptive Statistics for NAV

\begin{tabular}{lc}
\hline Parameters & NAV (\%) \\
\hline Mean & 9.41 \\
Median & 9.43 \\
Std. Deviation & 1.67 \\
Minimum & 6.33 \\
Maximum & 12.25 \\
\hline
\end{tabular}

The mean NAV was 9.41 according to the results presented in Table 4.8. The minimum value of investment risk was found to be 6.33 in 2009 and a maximum of 12.25 in 2016 . The descriptive statistics also presented a median of 9.43 and a standard deviation of 1.67 .

\subsubsection{NAV Panel Plot and Trend}

The study further sought to establish the panel plot and trend of NAV for a period of nine years ranging from 2009 to 2017. The results are presented in Figure 4.2.

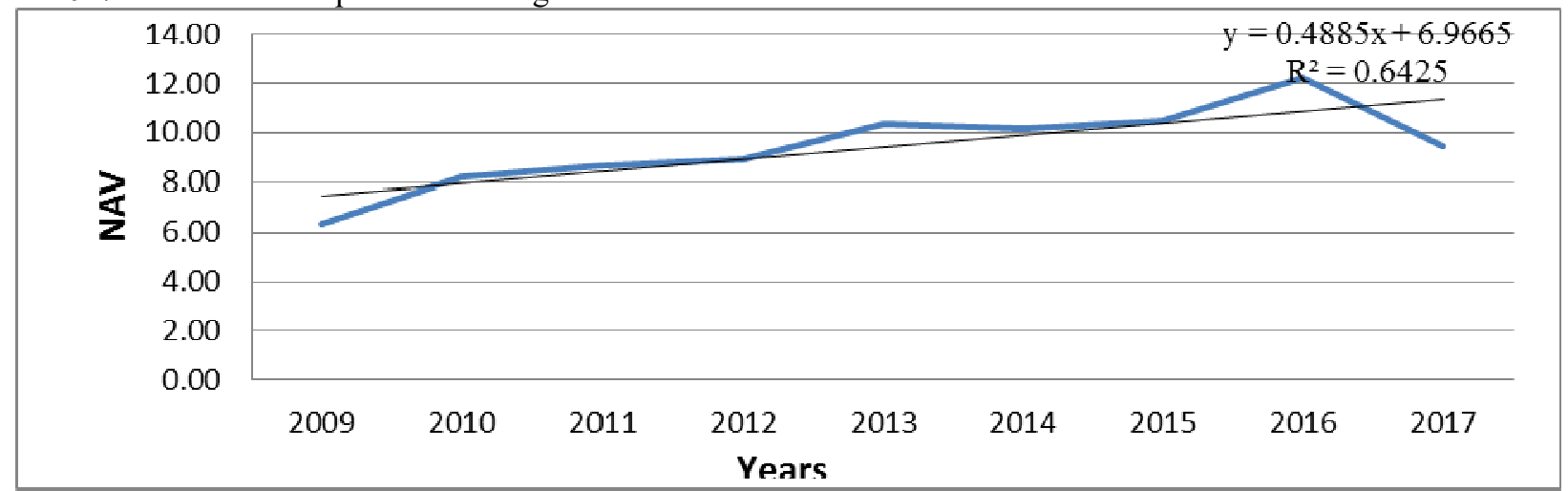

Figure 4.2: NAV Panel Plot and Trend

The study established a panel plot and trend line for the nine-year period. The curve has the peak at the year 2016 and the lowest point at the year 2009. According to trend line that was plotted, there is a positive gradient of 0.4885 with a y-axis intercept of 6.9665 . Kennedy (2015) also reported a positive gradient in the time series model predicting the NAV of asset allocation in mutual funds. According to the resultant $\mathrm{R}^{2}=0.6425$ of the trend line, time as the independent variable explains a large proportion of $64.25 \%$ of the change observed in the investment risk with $35.75 \%$ being explained by the error term.

\subsubsection{Unit Trust Price Volatility}

The study sought to establish the unit trust price variation as reflected by the standard deviation of Net asset value. The results of unit trust price volatility for equity fund among CMA listed unit trusts in Kenya using the descriptive statistics namely mean, median, and standard deviation as presented in Table 4.9.

\section{Table 4.9: Price Volatility for Equity Fund}

\begin{tabular}{lc}
\hline Parameters & Price Volatility (\%) \\
\hline Mean & 8.92 \\
Median & 8.86 \\
Std. Deviation & 1.21 \\
Minimum & 6.25 \\
Maximum & 10.23 \\
\hline
\end{tabular}

The mean unit trust price volatility was realized to be $8.92 \%$ according to the results presented in Table 4.9. In addition, the minimum value of unit trust price volatility was found to be 6.25 in 2009 and a maximum of $10.23 \%$ in 2015. The descriptive statistics also presented a median of $8.86 \%$ and a standard deviation of $1.21 \%$.

\subsubsection{Unit Trust Price Volatility Panel Plot and Trend}

The study further sought to establish the panel plot and trend of unit trust price volatility for a period of nine years ranging from 2009 to 2017. The results are presented in Figure 4.3. 


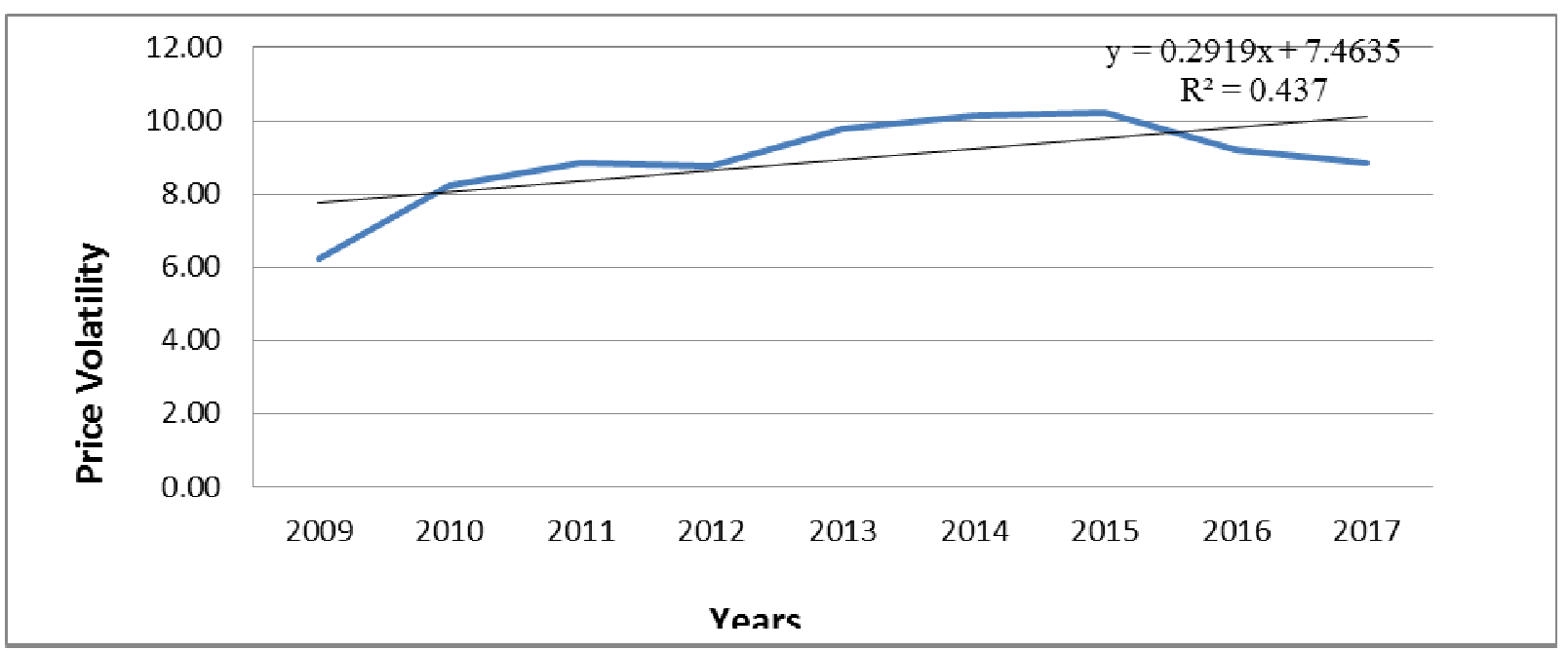

Figure 4.3: Unit Trust Price Volatility Panel Plot and Trend

The study established a panel plot and trend line for the nine-year period. The curve has the peak at the year 2015 and the lowest point at the year 2009. According to trend line that was plotted, there is a positive gradient of 0.2919 with a y-axis intercept of 7.4635. The results concur with John, E. M. (1995) who also reported a positive gradient trend in financial markets volatility in the G-7 countries. According to the resultant $\mathrm{R}^{2}=0.437$ of the trend line, time as the independent variable explains a proportion of $43.7 \%$ of the change observed in the unit trust price volatility with $56.3 \%$ being explained by the error term.

4.3.8 Effect of Investment Risk on Unit Trust Price Volatility among CMA Listed Unit Trusts in Kenya The study sought to establish the effect of investment risks on unit trust price volatility among CMA listed unit trusts in Kenya. The main test was a panel regression analysis and Karl Pearson Correlation as the confirmatory test at $5 \%$ levels of significance. The tests facilitated in testing research hypothesis; $\mathbf{H}_{\mathbf{0 1}}$. Investment risk has no statistical significant effect on unit trust price volatility among CMA listed unit trusts in Kenya.

\section{Table 4.10. Descriptive statistics}

\begin{tabular}{lcc} 
Parameters & IR & UTPV(\%) \\
\hline Mean & 5.98 & 8.92 \\
Median & 6.25 & 8.86 \\
Std. Deviation & 3.98 & 1.21 \\
Minimum & 0.81 & 6.25 \\
Maximum & 11.74 & 10.23 \\
\hline
\end{tabular}

The findings shown in Table 4.10 revealed that the mean of the investment risk is 5.98 with the median of 6.25 and a standard deviation of 3.98. It was also established that the minimum investment risk of 0.81 was recorded while the maximum of 11.74 . The unit trust price volatility established a mean of 8,92 , median of 8.86 , maximum of 10.23 and minimum of 6.25 . As indicated by the standard deviation of 1.21 , the price volatility is relatively stable.

\subsubsection{Correlation and Regression Analysis}

The researcher conducted Karl Pearson correlation analysis to test the relationship between financial risks investment risk and unit trust price volatility among CMA listed unit trusts in Kenya. The test on the relationship between investment risk and unit trust price volatility yielded correlation coefficient $r=-0.4366$, $p$ value $=0.002<0.05$ using the observations $1: 1-14: 9$ for $n=85, \boldsymbol{\alpha}=0.05$. This implies that there is a negative moderate relationship between investment risk and unit trust price volatility that is statistically significant at $5 \%$ levels of significant.

The researcher performed regression analysis to investigate the effect of investment risk on unit trust price volatility for equity fund among CMA listed unit trusts in Kenya. First the suitability of regression as a type of analysis for the study was tested and results indicated by regression Analysis of Variance (ANOVA) presented in Table 4.11. The effect of investment risk on unit trust price volatility was presented in the regression model summary presented in Table 4.12. The effect of investment risk was presented in the table of coefficients, which is Table 4.13. Finally, the regression model was fixed. 
Table 4.11: Panel Regression ANOVA

\begin{tabular}{lccccc}
\hline & Sum of Squares & df & Mean Square & F & p-value \\
\hline Regression & 1.783 & 1 & 1.783 & 19.550 & 0.0000 \\
Residual & 7.570 & 83 & 0.0912 & & \\
\hline Total & 9.353 & 84 & & & \\
\hline a Dependent Variable: Unit Trust Price volatility & & & \\
b Predictors: (Constant), Investment Risk & & & & \\
\hline
\end{tabular}

The $\mathrm{p}$-value $=0.000<0.05$ as displayed in the Regression ANOVA implies that regression analysis at $5 \%$ levels of significance is applicable for the study. This confirmed that the model fits well and the study could proceed conducting the regression analysis to test the effects of financial risk on unit trust price volatility for Equity Fund. Also the study established the fitness of the model by comparing the F- calculated 19.550 with F- critical $\mathrm{F} 0.05,1,84=3.96$. Since $\mathrm{F}$ - calculated was greater than $\mathrm{F}$ - critical, the study concluded that the model fits well.

Table 4.12: Regression Model Summary

\begin{tabular}{rrrrr}
\hline Model & $\mathrm{R}$ & $\mathrm{R}$ Square & Adjusted R Square & Standard Error of the Estimate \\
\hline 1 & $0.4366 \mathrm{a}$ & 0.1906 & 0.1808 & 0.3020 \\
\hline
\end{tabular}

a. Dependent Variable: PR

b. Predictors: (Constant) Investment Risk

The correlation coefficient $(\mathrm{R})$ value of 0.4366 revealed a strong positive relationship between financial risk and unit trust price volatility. According to R-Square value $=0.1906$ as presented in table 4.12 , the effect of the investment risk contributed an extent of $19.06 \%$ of the dependent variable that is on unit trust price volatility for equity fund that is satisfactory since p- value was less than 0.05 while $80.94 \%$ is attributed by other variables. The standard error of the estimate was 0.3020 which is quite low and represents a well-organized data results. Hair, Anderson, Tatham and Black (2013) suggested in a scholarly research that focuses on marketing issues, $\mathrm{R}^{2}$ value of 0.50 for endogenous latent variables can as a rough rule of thumb be described as moderate. According to Moore, Notz \& Flinger (2013), a model with $F(0.05,1,65)=2.03, p=0.041, R^{2}=0.03$ is a weak predictor of association of variables.

Table 4.13: Regression Coefficients

\begin{tabular}{lccccc}
\hline & $\mathrm{B}$ & Standard Error & Beta & $\mathrm{t}$ & $\mathrm{p}$-value \\
\hline (Constant) & 2.384 & 0.834 & & 2.859 & 0.010 \\
Investment Risk & -0.362 & 0.143 & -0.472 & -2.531 & 0.021 \\
\hline
\end{tabular}

Pooled OLS, using 85 observations Included 14 cross-sectional units Time-series length: minimum 1, maximum 9

Dependent Variable: Unit Trust Price Volatility.

The regression coefficients as presented in Table 4.13 above were used to construct the regression model below. From the equity fund model, the constant value was found to be $\boldsymbol{\beta}_{0}=2.384$ which indicate that unit trust price volatility is $2.384 \%$ if the independent variables states at zero level. Price Volatility $=\mathbf{2 . 3 8 4 - 0 . 3 6 2}$ IR. The effect of Investment Risk on unit trust price volatility recorded a coefficient of regression $\boldsymbol{\beta}_{5}=-0.362 \mathrm{p}$ value $=0.021<0.05$. This implies that Investment Risk have a negative effect on unit trust price volatility that is statistically significant at 5\% levels of significance. An increase in one unit of investment risk leads to $36.2 \%$ decrease in unit trust price volatility, holding other factors constant. Return $=$ Risk free rate $+\beta$ (Risk premium) is the association between risk and returns which are direct proportional. This proves Pandey (2008) argument on risk and returns that the higher the risk, the higher the returns in the long run but proper balance should be maintained to maximize the value of firm's shares. Hsu and Chow 2013) in the study the effect on investment risk taking on house money reported that investment risk has a negative significant effect on house money implying a concurrence in the research findings.

\section{CONCLUSION}

The research conducted was based on the notion that financial risk does not have statistical significant effect on unit trust price volatility among CMA listed firms in Kenya. The pretested record survey sheet was used to collect secondary data for both dependent and independent variables and to add value to the secondary data. Out of 19unit trust firms, 14 representing $73.6 \%$ responded. The independent variables of the research were tested for Multicollinearity and independence using Variance inflation factor test. Normality test was carried using Shapirowilk test for all the variables, Durbin - Watson test was used to detect autocorrelation, Wooldridge Drukker test was used to test for the presence of serial correlation, modified Wald test was used to test the presence of Heteroskedasticity. The panel plot and trend line were plotted for all variables against time to test for the effect on time on the independent and dependent variables. Panel regression analysis was used to test the effect of independent variables. The hypothesis formulated was tested empirically guided by the objective. 
The study revealed that CMA listed unit trust recorded investment risk with a mean of 5.98 and standard deviation was 3.98, The maximum investment risk was 11.74 in 2009 while the minimum of 0.81 was recorded in the year 2017. The Panel plot and trend portrayed a negative gradient. The individual regression analysis on the effect of investment risk on unit trust price volatility indicated a negative significant effect at $5 \%$ levels of significance at $\mathrm{p}$ - value $<0.05$. This led to the rejection of the null hypothesis that investment risk has no statistical significant effect on unit trust price volatility among CMA listed unit trusts in Kenya at 5\% level of significance.

The study revealed that CMA listed unit trust recorded Net Asset Value with a mean of 9.41, standard deviation of 1.67, minimum value to be 6.33 in 2009 and a maximum of 12.25 in 2016. The panel plot and trend for NAV had a positive effect for NAV. The study revealed that CMA listed unit trust recorded unit trust Price Volatility with a mean of 8.92, standard deviation was 1.21 , maximum UTPV was 10.25 in 2015 while the minimum of 6.25 in 2009. The trend for UTPV had a positive gradient. The resultant panel regression model was the effect of investment risk on unit trust price volatility among CMA listed firms in Kenya for Equity fund. PV $=2.384-0.362 \mathrm{IR}$

After performing the Karl Pearson correlation as a confirmatory test, the model yielded correlation coefficient $\mathrm{r}=-0.4366$, $\mathrm{p}$-value $=0.002<0.05$ showing a moderate negative relationship between investment risk and unit trust price volatility that is significant at 5\% levels of significance. The study found an R-Square value $=0.1906$ showing the effect by the interest indicator of $19.06 \%$ of unit trust price volatility with the rest proportion $(80.94 \%)$ being explained by extraneous variables as well as the error term.

The panel regression was used to test the effect of Investment Risk on unit trust Price Volatility. The model recorded a coefficient of regression $\boldsymbol{\beta}_{1}=-0.362 \mathrm{p}$-value $=0.021<0.05$ implying negative effect that is significant at $5 \%$ levels of significance. The study findings justified the rejection of the null hypothesis, stating that investment risk has no statistical significant effect on unit trust price volatility among CMA listed unit trusts in Kenya. Therefore, the alternative hypothesis that states that investment risk has a statistical significant effect on unit trust price volatility among CMA listed unit trusts in Kenya was not reject. This informed the conclusion that investment risk has a statistical significant effect on unit trust price volatility that is significant at $5 \%$ levels of significance though on a low scale.

\section{Recommendations of the Study}

As a result of investment risk having statistical significant effect on unit trust price volatility, the study made the following recommendations;

The unit trust firms should minimize the cost of operation through proper control systems such as EOQ (Economic Order Quantity). This will ensure that the firms maintain the ideal level of operation that has an effect on stabilizing the unit trust price. The management ensure that the staff is qualified to perform the duties assigned. All these has an impact on the unit trust price levels.

The Board of Directors of the Unit trust firms should engage fund managers with sound financial knowledge or retain the fund managers on financial matters to ensure that they understand the macro and micro economic variables which increase investment risk. This will automatically stabilize the unit trust prices. The unit trust firm's management should ensure that the financial position of the firm is stable by investing in assets whose returns are less risky. The investment with higher returns deters investors from joining other unit trust firms that are more lucrative.

\section{Policy Implication}

The Government of Kenya through the ministry of national treasury has created CMA to oversee the development and success of unit trust. The act should however be reviewed to give the authority the inspection mandate on the unit trust to make them efficient and conform to financial international standards to be in line with the economic pillar of vision 2030. The board of directors of unit trust firms should engage qualified and experienced fund managers and chief financial officer. There should be expertise in financial and investment matters as a control system mechanism to stabilize unit trust prices.

\section{Suggestions for Further Studies}

The study was limited to effect of investment risk on unit trust price volatility and further research can be interesting on other economic factors which affect the unit trust price volatility. Future research is required on the effect of other types of risk on unit trust price volatility and other extraneous factors. Investment risk measurement was limited to annual income to expenses ratio. Further research can be of interest using other investment risk measurements. The unit trust price volatility measure was standard deviation of NAV. Further research can be done using the standard deviation of unit trust closing price. The study only dealt on firms holding equity fund, future research can be done on other funds such as money market, balance income and fixed fund. The study was limited to unit trust firms listed in CMA in Kenya, altering the geographical region can be a subject for further research. 


\section{References}

Andrew, M., Sam, A. A., \& Frank, S. (2016). Realism skill and incentives: Current and future trends in investment risk management and investment performance. International Review of Financial Analysis 43, 31 - 40.

Balvers, R. (2000). Mean reversion cross National stock market and parametric contraction investment strategies. Journal of finance, 55(1), $745-183$.

Bchini, B. (2013). "The relationship between country risk management and perennially of Tunisian exporting companies', Journal of business studies quarterly, 5(2), 41-55.

Bodie, K., Kane, A., \& Marcus, A. J. (2008). Investment. McGraw Hill, New York.

Brooks, P. (2013). Risk Tolerance essential behaviour \& misunderstand, Migal.

Brown, C., Keith, G., \& Reilly. K. F. (2000). "Investment analysis and portfolio management” 6th edition, Druden Press.

Budiono, D., P. (2009). The analysis of mutual fund performance: Evidence from U.S. Equity mutual Funds. Indonesia

BusinessToday. (2013). CMA Licenses first ethical fund.

Cameron, S. (2005). Econometrics. New York: McGraw, Hill Education.

Cao, C., \& Petrasek, L. (2014). Liquidity risk and institutional ownership. Journal of financial markets, 17, 1-52.

Capital Market Regulatory. (2001). Kenya gazette Nairobi

Carlson, M., (2006,). "A brief history of the 1987 Stock market crash." Finance and economics discussion series. Divisions of research \& statistics and monetary affairs, Federal reserve board, Washington, D.C.

CBK. (2016). Governors report. Nairobi: Kenya Gazette.

Cheng A., \& Nasir, A. (2010). Earning response coefficients and the financial risks of China commercial banks. International review of business research papers, 6(3), 178-188.

Cheng, C., W. \& Nasir, L. B. (2010). Macroeconomics determinant of sovereign credit ratings, International business research journal, 14 (3), $346-358$

Child, D. (1990). The essentials of factor analysis, 2nd edition. London: Cassel education Limited

Chow, E., \& Hsu, Y. (2013). "The effect of investment risk taking on the House Money", Pacific- Basin finance journal, 21 (1), $1102-1115$.

CMA. (2015). Annual report and account. Nairobi: Kenya Gazette.

Collective Investment scheme regulations, (2001). Full compliance report with capital market. Kenya Gazette.

Cornet, M.M., Mcruit, J.J., \& Tehrainian, H (2009). Corporate government and earnings management at large Us bank holding companies. Journal of corporate finance 15(4), 412- 430

Correa, R., Lee, K. H., Sapriza, H., \& Suarez, G. A. (2014). Sovereign credit risk, banks' government support, and bank stock returns around the world. Journal of money, credit \& banking, 46(1), 93-121.

Creswell, J. B. (2003). Research design: Qualitative, quantitative and mixed methods approach. London: Sage Publications.

Cronbach, L. J. (1951). Co-efficient alpha and internal structure of tests. Psychometrical.

Economic Survey. (2014). Kenya Gazette.

Economic Survey (2015). Kenya Gazette

Enarson, D., Kennedy, S. M., \& Miller, D. L. (2004). Choosing a research study design and selecting a population to study. International journal of tuberculosis and lungs disease, 8 (9), 1151- 1156.

Fama, E.F. (1970). Efficient capital markets: A review of theory and empirical work. The journal of finance, 2 , $383-417$

Firer, C. (2001). 'The persistence of performance of south African unit trusts': South African journal of business management, 32(2), 1-8.

Gachiri, J. (2013). Genghis Capital now starts selling Shariah . unit trusts. Business daily .

Garson, D.G. ( 2012). Testing statistical assumptions. Ashebora: Statistical associate publishing blue Books series.

Gilchrist, C. (1976). Unit Trust: What every investor should know. $1^{\text {st }}$ edition.Oxford university press

Girard, E., \& Omran, M. (2007). "What are the risks when investing in thin emerging equity markets: Evidence from the Arab world", Journal of international financial markets, Institutions and money, 17(1) 102-123.

Gliem, A., \& Gliem, R. (2003). Calculating, interpretation and reporting Cronbach's reliability co-efficient for Likert Types of Scales.

Gujarati, D. N. (2004). Basic Econometrics, Tata McGraw Hill, India.

Hair, J. F., Anderson, R. E., Tatham, R. L. \& Black, W. C. (2013). Multivariate Data analysis (6 ${ }^{\text {th }}$ ed.). New York: Macmillan.

Hao, S., \& Zhang, G. (2007). Relative firm profitability and stock price sensitivity to aggregate information. Hong Kong University of science and technology, 4(2), 155-186.

Hsiao, C. (2013). Analysis of panel data, second edition, Cambridge University press. New York.

Isik, N., Acar, M., \& Işık, B. (2004). "Risks of investing in the Russian stock market: lessons of the first decade", CEFIR / NES Working paper series. 
Jamaldeen, F. (2014). "Risks unique to islamic finance". Islamic finance.

Jones, C. P. (2012). Investments: Analysis and management. Hoboken

Kamau J., \& Kariuki, P. (2014). Effect of financial risk on equity shares price volatility in kenya. Orso journal, 13 (3), $1123-1154$.

Kennedy, P. ( 2008). A guide to econometrics, fifth Edition, MIT press.

Kennedy, L. D. (2015). Time seris models to predict the net asset value of an asset in allocation mutual fund, Publisher Springer.

Kothari, C. K. (2004). Research Methodology, Methods and Technique. New Delhi: New AgeInternational Limited Publishers.

Lewis, M. (2010). The Big Short. NY: Norton.

Lowenstein, R. (2000). When genius failed. NY: Random House

Liang, S.X., \& Wei, J. K. C. (2012). Liquidity risk and stock returns around the world. Journal of banking and finance 36(12), 3247-3288.

Li, M. Y., \& Wu. J, S. (2014). Analyst forecast dispersion and stock return; Quartile regression approach, Journal of behavioral finance, 15(3), $175-183$

Mabhunu, M. (2004), 'The Market efficiency hypothesis and the behaviour of stock returns on the JSE Securities Exchange': University of Rhodes, South Africa.

Maina, K. (2013). Risk and Returns of Investments Held by Insurance Companies in Kenya. journal- University of Nairobi .

Malkiel, B.G. (2003). The efficient market hypothesis and its critics. Princeton University.

Malkiel, B. (1996), 'Reflections on the efficient market hypothesis: 30Years Later': The financial review, 40(2005), $1-9$.

Malkiel, B. (1996), 'The efficient market hypothesis and its critics': Working Paper Princeton University, Princeton, USA.

Moore, D. S., Notz, W. I., \& Flinger, M. A. (2013). The best practice of statistics $\left(6^{\text {th }}\right.$ ed). New York: Freeman and company.

Mugenda, M. O., \& Mugenda A. G. (2004). Research methods: Quantitative and qualitative approaches. Nairobi: ACTS Press

Kamil, N. M., Subramaniam, M., Ali, E. H., Musah, B. M., \& Alex, A. (2018) "Factors influencing the selection of unit trust funds among Malaysian retail investors", Journal of Islamic accounting and business research, $9(2) ; 155-170$

Pandey, I. M. (2008). "Financial management", 10th edition. New Delhi: Vikas Publishing House Pvt. Limited.

Pretorius, M., \& Wolmarans, H. (2006). 'The unit trust industry in South Africa from 1965 to June 2005: Are investors better Off?' Meditari accountancy research, 14(1), 49-67.

Saunders, M., Lewis, P., \& Thornhill, A. (2007). Research methods for business Students. London: Financial Times.

Sharpe, W. (1996). Mutual fund performance. Journal of business, 39 (1), 119- 138.

Shikuku, R. M. (2012). Effect of behavioural factors on investment decision making by unit trusts in kenya. unpublished( University of Nairobi).

Soh, W. N., Cheng, A., \& Nassir, A. (2009). The effect of financial risk on the earnings response in Thailand bank stock. International research journal of finance and economics, 31, 55-65.

Pandey, R. C., \& Singh, N. (2008). Impact of working capital management in the profitability of hindalco industries limited. ICFA journal of financial economics 34 (3), 134 -147.

Spiegel, S. (2008). Non parametric statistics for behavioral sciences. New York: McGraw-Hill Publishing Company Inc.

Spierdijk, L., Bikker, J.A., \& Vander Hoek, P. (2010). Mean reversion in international stock markets: an empirical analysis of the 20th century, DNB Working Paper 247, De Nederlandsche Bank, Amsterdam.

Steiger, F. (2010). The impact of credit risk and implied volatility on stock returns. Cambridge, MA: Harvard University.

Stroeder, R. M. (2008). Effect of financial risk on profitability of commercial banks in Kenya. Economics and finance, 202 - 216.

Tari, R., \& Yıldırım, D. Ç. (2009). Political risk and stock price volatility: The case of Hong Kong', Pacific-basin finance journal, 4(2-3), 259-275.

Verbeek, M. (2004). A guide to modern econometrics. (2nd ed). Southern Gate, Chichester, West Sussex, England Hoboken, NJ: John Wiley \& Sons.

Wooldridge, J. M. (2002). Econometrics analysis of cross- section and panel data, MIT press

WTO. (2015). Economic survey. New York: United nation . 